\title{
IMPLEMENTASI PERMAINAN TRADISIONAL (PETAK UMPET) TOPENG HEWAN TERHADAP KETERAMPILAN MOTORIK KASAR ANAK USIA 5 SAMPAI 6 TAHUN KELOMPOK B DI PAUD TAAM MUHAJIRIN PALEMBANG
}

\author{
Eva Meliana Saputri ${ }^{1}$, Dr. Evia Darmawani,M.Pd.Kons ${ }^{2}$, \\ Santa Idayana Sinaga,M.Pd ${ }^{3}$ \\ Email : evameliana26@yahoo.com¹,evia.syamsuddin@gmail.com², \\ santashmily@gmail.com ${ }^{3}$
}

\begin{abstract}
Abstrak : Masalah dalam penelitian ini adalah adakah pengaruh permainan tradisional (Petak Umpet) topeng hewan terhadap keterampilan motorik kasar anak usia 5 sampai 6 tahun kelompok B di PAUD TAAM Muhajirin Palembang. Tujuan dalam penelitian ini adalah untuk mengetahui pengaruh permainan tradisional (petak umpet) topeng hewan terhadap keterampilan motorik kasar anak usia 5 Sampai 6 Tahun kelompok B Di PAUD TAAM Muhajirin Palembang. Metode penelitian ini menggunakan penelitian eksperimen yaitu metode penelitian yang digunakan untuk mencari pengaruh perlakuan tertent terhadap yang lain dalam kondisi yang terkendali". Adapun Jenis penelitian yang digunakan adalah preexperimental designs dengan rancangan one-group pretest-posttest design. Populasi dalam penelitian ini seluruh Anak kelompok B di usia 5 Sampai 6 Tahun kelompok B Di PAUD TAAM Muhajirin Palembang, teknik pengambilan sampel yang digunakan adalah sampel jenuh. Data diperoleh melalui observasi dan dokumentasi. Pada Posttest kelas eksperimen dengan nilai rata-rata adalah 67, sedangkan pada Posttest kelas kontrol dengan nilai rata-rata 53,7 Pernyataan tersebut dapat dibuktikan dari hasil pengujian hipotesis yang diperoleh yaitu $t_{\text {hitung }}>t_{\text {tabel }}$ atau 36,9 $>2,048$ dengan taraf signifikan (a) 0.05 dan $\mathrm{dk}=30-2=28$. Maka dapat disimpulkan bahwa ada pengaruh implementasi terhadap keterampilan motorik kasar setelah dilakukan melalui permainan tradisional (petak umpet) topeng hewan pada anak usia 5 sampai 6 tahun kelompok B di PAUD TAAM Muhajirin Palembang tahun 2019.
\end{abstract}

kata kunci: Permainan Tradisional (Petak Umpet), Motorik Kasar.

\section{PENDAHULUAN}

Anak usia dini adalah sosok individu yang sedang menjalani suatu proses perkembangan dengan pesat dan fundamental bagi kehidupan selanjutnya. Perkembangan anak usia dini sifatnya holistik, yaitu dapat berkembang optimal apabila sehat badannya, cukup gizinya, dan mendapatkan pendidikan secara baik dan benar. Selain itu perkembangan anak berlangsung secara berkesinambungan sesuai dengan tahapan perkembangannya..

Dalam nuansa tersebut perkembangan setiap anak berbeda sesuai dengan tempo dan irama. Berbagai faktor yang menyebabkan perbedaan tersebut diantaranya usia, perkembangan fisik, budaya, latar belakang keluarga, dan tempat tinggal.

Dalam masa perkembangan tersebut, berbagai aspek dikembangkan, 
diantaranya motorik halus (fine motor skills) dan motorik kasar (gross motor skills). Ketika otot-otot badan cenderung lebih kuat dan kokoh, maka keterampilan-keterampilan yang menggunakan otot tangan dan kaki sudah mulai berfungsi. Perkembangan fisik seperti berjalan, berlari, melompat dan sebagainya, membutuhkan keterampilan motorik agar otot syaraf yang mulai tumbuh dapat berfungsi dengan baik.

Seiring dengan pertumbuhan fisik yang beranjak matang, maka keterampilan motorik anak sudah terkoordinasi dengan baik. Sehingga setiap gerakannya sudah selaras dengan kebutuhan atau minatnya. Anak cenderung menunjukkan gerakangerakan yang cukup gesit dan lincah dalam semua aspek yang dilakukan.

Kenyataan di lapangan, beberapa lembaga Pendidikan Anak Usia Dini, upaya untuk menstimulus aspek perkembangan fisik anak usia dini lebih banyak difokuskan pada keterampilan motorik halus, sedangkan motorik kasar belum banyak mendapat perhatian, contohnya anak sering kali dilatih menulis di atas kertas dibandingkan bermain permainan tradisional bersama guru di lapangan. Walaupun media permainan tersebut murah dan mudah menggunakannya dengan memanfaatkan benda disekitar seperti pemanfaatan pohon ataupun tanaman lainnya pada saat mencari tempat persembunyian dalam permainan tradisional (petak umpet) topeng hewan.

Fenomena yang dikemukakan tersebut, berdasarkan hasil pengamatan peneliti di PAUD TAAM Muhajirin Palembang selama mengajar, diperoleh data bahwa 13 dari 18 anak, keterampilan motorik kasar masih belum berkembang sesuai aspek anak. Hal ini terbukti dari informasi guru mengajarkan keterampilan motorik kasar sebagai berikut : a) sebanyak 15 anak masih mengalami kesulitan dalam posisi lari seimbang tanpa terjatuh, b) sebagian besar anak belum mampu berjalan cepat sesuai tempo kaki kanan dan tangan kiri yang bergerak bergantian, c) sebagian besar anak belum mampu berlari pada saat bersembunyi di permainan tradisional petak umpet topeng hewan sesuai waktu yang ditentukan, d) sebagian besar anak dalam mengikuti permainan tradisional petak umpet topeng hewan masih belum 
mengikuti aturan serta masih dengan keegoisan.

Selain itu terkait dengan gerakan motorik kasar, bermain di masa sekarang dalam proses permainan saat di sekolah atau di rumah anak banyak terkait dengan kegiatan menggunakan permainan modern, contohnya anak lebih suka bermain gadget membuat beberapa aspek dari gerak motorik kasar ternyata masih sangat minim yang diperoleh anak baik di sekolah maupun di rumah.

Meskipun anak telah bermain, anak perlu dikenalkan dengan permainan tradisional, walaupun pada dasarnya permainan tradisional banyak membantu guru menstimulus perkembangan anak usia dini. Hal ini didasarkan pada jenis permainan tradisional tersebut mengandung unsurunsur kreatif, menarik dan menyenangkan anak.

Permainan petak umpet merupakan salah satu bentuk permainan edukatif. Diduga dapat membantu gerakan menstimulasi keterampilan motorik kasar anak usia dini. Cara bermain petak umpet yaitu mencari dan bersembunyi, dapat dilakukan minimal
2 orang. Pelaksanaan umumnya berada di luar ruangan.

Dalam permainan ini, ada dua peran, misalnya kucing dan tikus yaitu "si kucing" bertugas mencari dan "si tikus" yang bersembunyi. Si kucing ini perperan mencari teman-temannya yang bersembunyi. Permainan selesai setelah semua teman di temukan. Dan yang pertama ditemukanlah yang menjadi kucing berikutnya.

Berdasarkan uraian yang telah dikemukakan, peneliti tertarik melakukan penelitian dengan judul Implementasi Permainan Tradisional (Petak Umpet) Topeng Hewan Terhadap Keterampilan Motorik Kasar Anak Usia 5 Sampai 6 Tahun Kelompok B di PAUD TAAM Muhajirin Palembang.

\section{KAJIAN TEORITIK}

\section{Keterampilan Motorik Kasar}

Keterampilan motorik anak usia dini banyak menarik perhatian untuk dipahami dengan menelaah berbagai pengertian sebagaimana dikemukakan para ahli :

Menurut Susanto (2015:55), menjelaskan bahwa keterampilan motorik adalah "pada dasarnya 
berkembang sejalan dengan kematangan saraf dan otak, sehingga dapat dikatakan bahwa setiap gerakan sesederhana apapun yang dilakukan oleh anak merupakan hasil interaksi yang kompleks dari beberapa bagian sistem tubuh yang dikontrol oleh otak".

Kemudian Rahyubi (2016:211), menjelaskan keterampilan motorik adalah 'gambaran kemampuan motorik seseorang yang ditunjukan melalui penguasaan suatu gerakan. Dalam suatu proses pembelajaran motorik, seorang pembelajar diharapkan mampu menguasai keterampilan motorik, yaitu kemampuan seseorang untuk melakukan kemampuan suatu tugas gerak secara maksimal sesuai dengan kemampuannya'.

Dari pendapat para ahli di simpulkan bahwa keterampilan motorik adalah keterampilan persepsi motorik dapat mengalami penguasaan, kemampuan seseorang untuk melakukan suatu tugas gerak secara maksimal sesuai dengan kemampuannya sehingga dapat dikatakan bahwa setiap gerakan sesederhana apapun yang dilakukan oleh anak merupakan hasil interaksi yang kompleks.
Menurut Mursid (2015:12), motorik kasar adalah "melatih gerak jasmani berupa koordinasi gerakan tubuh pada anak seperti merangkak, berlari, berjinjit, melompat bergantung, melempar dan menangkap, serta menjaga keseimbangan".

Selanjutnya Umama (2016:9), menjelaskan motorik kasar adalah "kemampuan anak yang digunakan untuk mengontrol otot-otot besar, meliputi kemampuannya untuk duduk, berjalan, berlari, menendang, melompat, melempar, dan sebagainya”.

Dengan demikian, jelas tergambar bahwa motorik kasar adalah gerakan yang memerlukan tenaga karena dilakukan oleh otot-otot yang lebih besar berupa koordinasi gerakan tubuh pada anak, meliputi kemampuannya untuk duduk, berjalan, berlari, menendang, melompat dan sebagainya.

Sehingga, telah dipaparkan bahwa keterampilan motorik kasar adalah mengembangkan keterampilan persepsi motorik untuk melakukan suatu tugas gerak secara maksimal sesuai dengan kemampuannya yang memerlukan tenaga karena dilakukan oleh otot-otot yang lebih besar berupa koordinasi gerakan tubuh pada anak, meliputi 
kemampuannya untuk duduk, berjalan, berlari, menendang, melompat, melempar, dan sebagainya.

\section{Permainan Tradisional Petak Umpet Topeng Hewan}

Pendapat Yunus dalam Mulyani (2016:46), menjelaskan bahwa permainan tradisional adalah 'suatu hasil budaya masyarakat, yang berasal dari zaman yang sangat tua, yang telah tumbuh dan hidup hingga sekarang, dengan masyarakat pendukungnya yang terdiri atas tua muda, laki atau perempuan, kaya miskin, rakyat bangsawan, dengan tiada bedanya.

Menurut Mulyani (2016:60), permainan tradisional petak umpet dilakukan bahwa petak umpet adalah jenis permainan "cari dan sembunyi”" yang bisa dimainkan oleh minimal 2 orang yang umumnya berada di luar ruangan.

Dengan demikian permainan tradisional petak umpet merupakan permainan tradisional terbentuk dari aktivitas dari 2 orang yaitu ucing (artinya-kucing) dan sumput (artinyasembunyi) yang diturunkan dari satu generasi ke generasi berikutnya dan secara berkesinambungan.
Menurut Bangsawan (2019:18), manfaat permainan tradisional petak umpet diantaranya:

a. Menyenangkan, yaitu esensi dari bermain adalah memberi kesenangan.

b. Bersosialisasi, yaitu cara yang baik dan kondusif untuk belajar bersosialisasi.

c. Membuat anak aktif, yaitu aktif bergerak yang sangat bermanfaat bagi kesehatandan pertumbuhan.

d. Belajar menghafal hitungan, yaitu terbantu menghafalkan hitungan melalui permainan.

e. Melatih sportivitas dan fair play, yaitu anak akan belajar menerima kekalahan untuk dapat terus melanjutkan permainan.

f. Melatih kreativitas, yaitu anak harus kreatif mencari ide persembunyian yang tidak sama dengan pemain lainnya.

g. Belajar taat aturan, yaitu mematuhi aturan yang disepakati bersama.

Adapun cara bermaian petak umpet menurut (Mulyani, 2016:60) sebagai berikut 
a. Anak terlebih dahulu memulai dengan hompimpa untuk menentukan siapa yang menjadi "kucing". Si kucing ini nantinya akan memejamkan mata atau berbalik sambil berhitung.

b. Dalam permainan tersebut, konsentrasi si kucing terpecah manjadi dua. Di satu sisi ia harus mencari dan menemukan temannya yang bersembunyi, di sisi lain ia pun harus menjaga "benteng" supaya tidak diambil alih oleh teman yang bersembunyi.

c. Jika si kucing menemukan temannya, ia akan menyebut nama temannya sambil berlari menuju "benteng" markas.

d. Si kucing bergerilya menemukan teman-temannya yang bersembunyi, salah satu anak dapat mengendapendap menuju markas atau benteng jika berhasil menyentuhnya, maka semua teman-temannya yang sebelumnya ditemukan oleh kucing dibebaskan.

e. Permainan selesai setelah semua teman ditemukan. Orang yang pertama ditemukan yang menjadi kucing berikutnya.

Dari penjelasan di atas bahwa permainan petak umpet dilakukan dengan menentukan peran si ucing. Dalam hitungan tertentu anak-anak mencari tempat persembunyian. Disinilah peneliti menggunakan topeng untuk memudahkan peran ucing dalam memanggil nama temannya yang bersembunyi. Permainan terus dilakukan sehingga teman yang ditemukan ucing pertama kali akan menggantikan posisi ucing selanjutnya.

\section{METODOLOGI PENELITIAN}

Variabel adalah suatu objek yang menjadikan dasar dari sebuah penelitian yang mempunyai variasi tertentu yang menyangkut aspek yang diteliti untuk dipelajari. Menurut Arikunto dalam Siyoto (2015:50), variabel penelitian adalah suatu objek penelitian atau apa yang 
menjadi perhatian satu titik perhatian suatu penelitian.

$$
\text { Selanjutnya }
$$

Sugiyono (2017:61), macam-macam variabel dalam penelitian dibedakan menjadi dua yaitu variabel independen atau sering disebut variabel bebas adalah variabel yang mempengaruhi atau yang menjadi sebab perubahannya atau timbul variabel dependen. Variabel dependen atau variabel terikat adalah variabel yang dipengaruhi atau yang menjadi sebab akibat, karena adanya variabel bebas.

Berpedoman pada pendapat tersebut maka variabel dalam penelitian meliputi variable independent atau variabel bebas adalah permainan tradisional (petak umpet) topeng hewan dilambangkan $\mathrm{X}$ sedangkan variabel dependent atau variabel terikat adalah keterampilan motorik kasar dilambangkan Y.

Menurut

mengungkapkan bahwa "Metode penelitian adalah cara yang digunakan oleh peneliti dalam mengumpulkan data penelitiannya". Metode yang digunakan dalam penelitian ini adalah metode preexperimental designs dengan rancangan one-group pretest-posttest design.

Tahap-tahap yang akan dilakukan dalam penenlitian ini yaitu:

a. Tahap Pemberian Tes Awal (Pretest)

Pada tahap ini anak-anak diajak untuk bermain berupa permainan lompat tali. Tes ini hasil pretest menunjukkan tidak signifikan, maka peneliti dapat melanjutkan ke tahap pemberian perlakuan (treatment).

b. Tahap Pemberian Perlakuan (Treatment)

Memberikan perlakuan (treatment) peneliti memberikan perlakuan kegiatan yang dapat mempengaruhi keterampilan motorik kasar anak dengan melakukan kegiatan permainan tradisional (petak umpet) topeng hewan.

c. Tahap Pemberian Tes Akhir (Posttest)

Memberikan (posttest) kepada anak untuk diajak kembali bermain lompat tali. Hal ini dilakukan untuk mengetahui pengaruh pemberian perlakuan 
terhadap anak-anak. Hasil akhir dari tes ini, diduga ada pengaruh permainan tradisonal (petak umpet) topeng hewan terhadap kemampuan motorik kasar anak.

\section{HASIL DAN PEMBAHASAN}

Hasil dari penelitian data diperoleh selama 2 (dua) minggu menggunakan teknik dokumentasi dan observasi dengan dengan sumber anak usia 5 sampai 6 tahun kelompok B di PAUD TAAM Muhajirin Palembang tahun 2019. Setelah data terkumpul menggunakan data rumus statistik diolah dan dianalisa untuk mengetahui adanya implementasi terhadap keterampilan motorik kasar. Melalui eksperimen permainan tradisional (petak umpet) topeng hewan pada anak usia 5 sampai 6 tahun kelompok B di PAUD TAAM Muhajirin Palembang Tahun 2019.

Penelitian ini dilakukan dengan subjek penelitian seluruh kelompok B sebagai populasi, dan sampel dengan jumlah 30 anak sebagai kelas eksperimen, dan sebagai kelas kontrol.

Sebelum dilaksanakan penelitian ini, peneliti terlebih dahulu melakukan observasi awal pada anak usia 5 sampai 6 tahun kelompok B di PAUD TAAM Muhajirin Palembang tahun 2019. Selanjutnya peneliti membuat lembar ceklis untuk memperoleh gambaran tentang kemampuan motorik kasar anak.

\section{Tabel 1. Lembar Instrumen Peserta} Didik Implementasi Permainan Tradisional (Petak Umpet) Topeng Hewan Terhadap Keterampilan Motorik Anak

\begin{tabular}{|c|c|c|c|c|c|}
\hline \multirow[t]{2}{*}{ No } & \multirow[t]{2}{*}{ Item Observasi } & \multicolumn{4}{|c|}{$\begin{array}{c}\text { Skor } \\
\text { Penilaian }\end{array}$} \\
\hline & & 1 & 2 & 3 & 4 \\
\hline 1 & $\begin{array}{l}\text { Anak berjalan } \\
\text { melewati bebatuan } \\
\text { dengan seimbang. }\end{array}$ & & & & \\
\hline 2 & $\begin{array}{llr}\text { Anak } & \text { berjalan } \\
\text { sejauh } & 3 & \text { meter } \\
\text { dengan } & \text { koordinasi } \\
\text { tangan dan } & \text { kaki } \\
\text { yang selaras. }\end{array}$ & & & & \\
\hline 3 & $\begin{array}{lr}\text { Anak } & \text { berjalan } \\
\text { mendahului } 5 \text { orang } \\
\text { temannya } \\
\text { cepat. }\end{array}$ & & & & \\
\hline 4 & $\begin{array}{l}\text { Anak berjalan cepat } \\
\text { menuju benteng } \\
\text { dalam waktu } 20 \\
\text { detik. }\end{array}$ & & & & \\
\hline 5 & $\begin{array}{l}\text { Anak berjinjit } \\
\text { melewati tali } \\
\text { sebanyak } 2 \text { kali. }\end{array}$ & & & & \\
\hline 6 & $\begin{array}{l}\text { Anak berjinjit secara } \\
\text { mengendap-endap } \\
\text { menuju benteng. }\end{array}$ & & & & \\
\hline 7 & $\begin{array}{l}\text { Anak melatih } \\
\text { keseimbangan } \\
\text { dengan berjinjit } \\
\text { selama 5 detik }\end{array}$ & & & & \\
\hline 8 & $\begin{array}{l}\text { Anak berjinjit } \\
\text { melewati tali yang di } \\
\text { letakan di tanah. }\end{array}$ & & & & \\
\hline 9 & $\begin{array}{l}\text { Anak berlari sejauh } \\
5 \text { meter tanpa } \\
\text { terjatuh. }\end{array}$ & & & & \\
\hline 10 & $\begin{array}{l}\text { Anak mengambil } \\
\text { atribut } \text { (topeng) } \\
\text { dengan berlari. }\end{array}$ & & & & \\
\hline 11 & Anak berlari untuk & & & & \\
\hline
\end{tabular}




\begin{tabular}{|l|l|l|l|l|l|}
\hline & $\begin{array}{l}\text { bersembunyi dalam } \\
\text { hitungan 10 detik. }\end{array}$ & & & & \\
\hline 12 & $\begin{array}{l}\text { Anak berlari } \\
\text { mencari temannya } \\
\text { yang bersembunyi } \\
\text { sebanyak 5 orang. }\end{array}$ & & & & \\
\hline
\end{tabular}

Keterangan:

\begin{tabular}{|c|c|c|}
\hline Kriteria & Penilaian & $\begin{array}{c}\text { Rentang } \\
\text { Nilai }\end{array}$ \\
\hline Sangat sesuai & 4 & $76-100$ \\
Sesuai & 3 & $51-75$ \\
Tidak sesuai & 2 & $26-50$ \\
Sangan tidak sesuai & 1 & $0-25$ \\
\hline
\end{tabular}

Pengambilan data

dilaksanakan pada tanggal 15 Juli

2019 sampai dengan 28 Juli 2019.

Penelitian ini menggunakan teknik observasi sebagai teknik utama untuk memperoleh data. Data pembuktian tersebut dapat digambarkan sebagai berikut:

Tabel 2. Lembar Data Pretest Keterampilan Motorik Kasar

\begin{tabular}{|c|c|c|c|c|c|c|}
\hline \multirow[t]{2}{*}{ No } & \multirow{2}{*}{$\begin{array}{l}\text { Nama } \\
\text { Anak }\end{array}$} & \multirow{2}{*}{$\begin{array}{c}\text { Jenis } \\
\text { Kelamin }\end{array}$} & \multicolumn{3}{|c|}{$\begin{array}{c}\text { Aspek } \\
\text { Penilaian }\end{array}$} & \multirow[t]{2}{*}{ Skor } \\
\hline & & & 1 & 2 & 3 & \\
\hline 1 & $\mathrm{ADA}$ & $\mathrm{L}$ & 2 & 3 & 2 & 54 \\
\hline 2 & AR & $\mathrm{P}$ & 1 & 1 & 2 & 40 \\
\hline 3 & $\overline{\mathrm{AJ}}$ & $\mathrm{L}$ & 2 & 1 & 2 & 46 \\
\hline 4 & AKK & $\mathrm{L}$ & 2 & 3 & 2 & 54 \\
\hline 5 & B & $\mathrm{L}$ & 2 & 2 & 1 & 46 \\
\hline 6 & CKP & $\mathrm{P}$ & 1 & 2 & 2 & 46 \\
\hline 7 & CK & $\mathrm{P}$ & 2 & 2 & 2 & 50 \\
\hline 8 & DPS & $\mathrm{P}$ & 2 & 3 & 1 & 50 \\
\hline 9 & DJ & $\mathrm{L}$ & 2 & 2 & 3 & 54 \\
\hline 10 & $\overline{\mathrm{DH}}$ & $\mathrm{L}$ & 2 & 2 & 3 & 54 \\
\hline 11 & FFA & $\mathrm{P}$ & 2 & 1 & 3 & 59 \\
\hline 12 & IRP & $\mathrm{P}$ & 3 & 2 & 2 & 63 \\
\hline 13 & MAPU & $\mathrm{L}$ & 3 & 2 & 2 & 54 \\
\hline 14 & MFA & $\mathrm{L}$ & 3 & 3 & 2 & 63 \\
\hline 15 & SS & $\mathrm{P}$ & 3 & 3 & 3 & 73 \\
\hline
\end{tabular}

Tabel 3. Lembar Data Posttes Keterampilan Motorik Kasar

\begin{tabular}{|c|c|c|c|c|c|c|}
\hline \multirow[t]{2}{*}{ No } & \multirow[t]{2}{*}{$\begin{array}{l}\text { Nama } \\
\text { Anak }\end{array}$} & \multirow[t]{2}{*}{$\begin{array}{c}\text { Jenis } \\
\text { Kelamin }\end{array}$} & \multicolumn{3}{|c|}{$\begin{array}{c}\text { Aspek } \\
\text { Penilaian }\end{array}$} & \multirow[t]{2}{*}{ Skor } \\
\hline & & & 1 & 2 & 3 & \\
\hline 1 & ADA & $\mathrm{L}$ & 3 & 3 & 3 & 70 \\
\hline 2 & AR & $\mathrm{P}$ & 2 & 2 & 2 & 50 \\
\hline 3 & $\mathrm{AJ}$ & $\mathrm{L}$ & 3 & 3 & 2 & 63 \\
\hline 4 & AKK & $\mathrm{L}$ & 2 & 3 & 2 & 54 \\
\hline 5 & $\mathrm{~B}$ & $\mathrm{~L}$ & 3 & 3 & 2 & 63 \\
\hline 6 & CKP & $\mathrm{P}$ & 3 & 3 & 3 & 70 \\
\hline 7 & $\mathrm{CK}$ & $\mathrm{P}$ & 3 & 3 & 3 & 70 \\
\hline 8 & DPS & $\mathrm{P}$ & 2 & 3 & 3 & 63 \\
\hline 9 & DJ & $\mathrm{L}$ & 3 & 3 & 3 & 74 \\
\hline 10 & $\mathrm{DH}$ & $\mathrm{L}$ & 4 & 4 & 3 & 79 \\
\hline 11 & FFA & $\mathrm{P}$ & 3 & 3 & 3 & 70 \\
\hline 12 & IRP & $P$ & 3 & 3 & 3 & 70 \\
\hline 13 & MAPU & $\mathrm{L}$ & 3 & 4 & 4 & 79 \\
\hline 14 & MFA & $\mathrm{L}$ & 3 & 3 & 4 & 75 \\
\hline 15 & SS & $\mathrm{P}$ & 4 & 4 & 4 & 83 \\
\hline
\end{tabular}

Untuk membuktikan hipotesis yang telah di rumuskan dan untuk memperoleh suatu kesimpulan, maka data nilai lembar observasi yang diberikan akan dianalisis. Analisis data dalam penelitian ini menggunakan Uji Normalitas Data, Uji Homogenitas Data, dan Uji Hipotesis (Uji-t).

Hasil penelitian ditunjukkan berdasarkan pengelolaan dan perhitungan statistika didapatkan hasil yaitu thitung sebesar 0,05 dikonsultasikan dengan $\mathrm{t}$ tabel yang didapat dengan menggunakan nilai a - 0,05 dan dengan kebebasan (a-2) yaitu $(30-2=28)$ yaitu $t$ tabel 2,048 sehingga thitung $<\mathrm{t}$ tabel $(0,05<$ 2,048). Maka hipotesis nol (H0) 
ditolak dan hipotesis alternatif $\left(\mathrm{H}_{\mathrm{a}}\right)$ diterima. Hal ini berarti terdapat pengaruh yang signifikan pengaruh implementasi terhadap keterampilan motorik kasar setelah dilakukan melalui permainan tradisional (petak umpet) topeng hewan pada anak usia 5 sampai 6 tahun kelompok B di PAUD TAAM Muhajirin Palembang tahun 2019. Di mana hasil perhitungan data menunjukkan bahwa $\mathrm{t}$ hitung $<\mathrm{t}$ tabel sehingga diterimanya hipotesis alternatif (Ha).

Sejalan dengan penelitian yang dilakukan oleh Novia Agustin (2017) dalam penelitian yang berjudul "Pengaruh Aktivitas Permainan Petak Umpet Kata Terhadap Perkembangan Keaksaraan Anak Kelompok B Di TK Bhakti Kartika Pahayu Jaya Lampung Barat Tahun Ajaran 2016/2017”. Berdasarkan hasil perhitungan didapatkan bahwa permainan petak umpet kata dapat meningkatkan perkembangan keaksaraan pada anak. Artinya permainan tradisional dapat meningkatkan berbagai aspek perkembangan pada anak terutama aspek motorik kasar anak.
Dari hasil penelitian tersebut permainan tradisional (petak umpet) topeng hewan dapat mempengaruhi keterampilan motorik kasar pada anak. Hasil penelitian sesuai dengan teori dari Bangsawan (2019:17), petak umpet adalah permainan yang terdapat hampir semua tempat di belahan dunia, di Amerika misalnya, permainan ini diberi nama Hide and Seek, di Spanyol EL escondite, di Perancis Jeude chache-chache, dan di Korea Selatan Sumbaggoggil. Cara bermainnya sama dengan yang lainnya, yang jaga harus menutup matanya sambil menghitung sampai 10 atau berapapun angka yang ditetapkan. Teman yang tidak berjaga langsung mencari tempat bersembunyi (ngumpet).

Dari pemikiran Bangsawan tersebut terlihat bahwa permainan petak umpet dapat meningkatkan motorik kasar anak. Anak-anak secara tidak langsung dalam permainan tersebut berlari, melompat dan gerakan motorik kasar lainnya.

Selain itu setelah penerapannya di kelas, permainan petak umpet sudah menunjukkan, perubahan yang cukup baik pada kemampuan 
motorik kasar anak di di PAUD TAAM Muhajirin Palembang tahun 2019, hal ini terbukti bahwa sebelum dilakukan penelitian kemampuan motorik kasar pada anak belum berkembang sesuai harapan masih membutuhkan stimulus yang tepat untuk mengembangkannya, namun setelah diadakan penelitian melalui permainan tradisional (petak umpet) topeng hewan pada anak terlihat pengaruh dan peningkatan yang signifikan dimana ada beberapa aspek yang menjadi acuan penilaian, yaitu: (1) Anak mampu berjalan melalui bebatuan dengan seimbang, (2) Anak mampu berjinjit dengan dua kaki, (3) Anak mampu berlari dengan tidak terjatuh dan bersembunyi sesuai dengan aturan permainan.

\section{KESIMPULAN DAN SARAN}

Berdasarkan hasil penelitian mengenai pengaruh permainan tradisional (petak umpet) topeng hewan terhadap keterampilan motorik kasar pada anak usia 5 sampai 6 tahun kelompok B di PAUD TAAM Muhajirin Palembang tahun 2019 dapat meningkatkan secara optimal keterampilan motorik kasar pada anak. Peningkatan tersebut dapat dilihat dari hasil perhitungan data, yaitu: pada Posttest kelas eksperimen dengan nilai ratarata adalah 67, sedangkan pada Posttest kelas kontrol dengan nilai rata-rata 53,7 Pernyataan tersebut dapat dibuktikan dari hasil pengujian hipotesis yang diperoleh yaitu $t_{\text {hitung }}$ $>t_{\text {tabel }}$ atau 36,9 > 2,048 dengan taraf signifikan (a) $0.05 \mathrm{dan} \mathrm{dk}=30$ $2=28$. Maka dapat disimpulkan bahwa hipotesis yang menyatakan implementasi terhadap keterampilan motorik kasar setelah dilakukan melalui permainan tradisional (petak umpet) topeng hewan pada anak usia 5 sampai 6 tahun kelompok B di PAUD TAAM Muhajirin Palembang tahun 2019 diterima kebenarannya.

Berdasarkan kesimpulan yang sudah peneliti paparkan, maka peneliti memberikan saran sebagai berikut :

a. Bagi Anak

Anak dapat mengenal permainan tradisional, sehingga anak tertarik dan termotivasi belajar untuk mencapai tingkat perkembangan yang optimal. 
b. Bagi Guru

Guru hendaknya mengenalkan permainan tradisional dalam kegiatan pembelajaran untuk mengembangkan setiap aspek perkembangan anak

c. Bagi Lembaga Sekolah Menyediakan berbagai macam fasilitas maupun yang mendukung dan menarik.

d. Bagi Peneliti Selanjutnya

Peneliti selanjutnya diharapkan dapat lebih mengenalkan permainan tradisional lainnya untuk perkembangan motorik kasar anak.

\section{DAFTAR PUSTAKA}

Arikunto, Suharsimi . (2015). Prosedur Penelitian Satuan Pendekatan Praktik. Jakarta: Rineka Cipta.

Bangsawan,Irwan P.Ratu. (2019). Direktori Permainan Tradisional. Sumatera Selatan: Dinas Pendidikan, Pemuda, Olahraga dan Pariwisata.

Mulyani,Novi. (2016). Super Asyik Permainan Tradisional Anak Indonesia. Yogyakarta: Diva Press.

Mursid. (2015). Belajar dan Pembelajaran PAUD.
Bandung: PT Remaja Rosdakarya.

Novia,Agustin. (2017). Pengaruh Aktivitas Permainan Petak Umpet Kata Terhadap Perkembangan Keaksaraan Anak Kelompok B Di TK Bhakti Kartika Pahayu Jaya Lampung Barat Tahun Ajaran 2016/2017. Universitas Lampung. Diakses 27 Maret 2019.

Rahayubi,Heri. (2016). Teori-Teori Belajar dan Aplikasi Pembelajaran Motorik. Majalengka: Nusa Media.

Sugiyono. (2017). Metode Penelitian Pendekatan Kuantitatif, kualitatif dan RND. Bandung: Alfabeta.

Susanto,Ahmad. (2015). Bimbingan dan Konselin Di Taman Kanak-Kanak. Jakarta: Prenadamedia Group.

Umama. (2016). Pojok Bermain Anak. Jogjakarta: CV. Diandra Primamitra Media. 